\title{
Response to a glucose tolerance test in early-lactation Holstein cows receiving a supplementation of biotin, folic acid, and vitamin $B_{12}$
}

\author{
M. Duplessis* ${ }^{\circ}$ and C. L. Girard $(1)$ \\ Centre de Recherche et Développement de Sherbrooke, Sherbrooke, Québec J1M 0C8, Canada
}

\begin{abstract}
The aim of the study was to evaluate glucose and insulin metabolism of cows receiving a supplementation of biotin $\left(\mathrm{B}_{8}\right)$, folic acid $\left(\mathrm{B}_{9}\right)$, and vitamin $\mathrm{B}_{12}\left(\mathrm{~B}_{12}\right)$ during the transition period. According to a $2 \times 2$ factorial arrangement, 32 cows were randomly assigned to 9 incomplete blocks according to their previous 305-d milk yield. Within each block, cows were randomly assigned to 1 of the following levels of biotin from -27 to $28 \mathrm{~d}$ relative to the parturition: (1) no biotin supplement $\left(\mathrm{B}_{8}-\right)$ or $(2) 20 \mathrm{mg} / \mathrm{d}$ of dietary biotin $\left(\mathrm{B}_{8}+\right)$. Within each level of biotin, the cows received either (1) 2-mL weekly intramuscular injections of saline $0.9 \% \mathrm{NaCl}$ $\left(\mathrm{B}_{9} \mathrm{~B}_{12}-\right)$ or $(2) 2.6 \mathrm{~g} / \mathrm{d}$ of dietary folic acid and $2-\mathrm{mL}$ weekly intramuscular injections of $10 \mathrm{mg}$ of vitamin $\mathrm{B}_{12}$ $\left(\mathrm{B}_{9} \mathrm{~B}_{12}+\right)$. An intravenous glucose tolerance test was performed at $25 \mathrm{~d}$ in milk. Baseline plasma glucagon, glucose, and nonesterified fatty acid concentrations did not differ among treatments. For $\mathrm{B}_{9} \mathrm{~B}_{12}+$ cows, baseline plasma insulin concentration and maximal glucose concentration after glucose administration were greater when also combined with biotin compared with no biotin combination, whereas there was no effect in $\mathrm{B}_{9} \mathrm{~B}_{12}-$ cows. There was no treatment effect on time to reach half-maximal glucose and insulin concentrations, glucose positive incremental area under the curve, and glucose and insulin clearance rates. Regarding insulin results, maximal plasma concentration and positive incremental area under the curve were respectively 51 and $74 \%$ greater for cows receiving the $\mathrm{B}_{8}$ supplement than for cows who did not. Moreover, plasma nonesterified fatty acid concentration nadir tended to be reached later for $\mathrm{B}_{8}$ cows. Insulin peak was reached earlier for cows in the group $\mathrm{B}_{9} \mathrm{~B}_{12}+$ than cows in $\mathrm{B}_{9} \mathrm{~B}_{12}-$, regardless of $\mathrm{B}_{8}$ supplementation. Under the current condi-
\end{abstract}

Received July 21, 2020.

Accepted September 7, 2020

*Corresponding author: melissa.duplessis@canada.ca tions, our results suggested that cows receiving a $B_{8}$ supplement had a reduced insulin sensitivity in early lactation. Insulin response was faster for $\mathrm{B}_{9} \mathrm{~B}_{12}+$ cows, but this was not translated into further improvements following the glucose administration challenge.

Key words: cyanocobalamin, folate, biotin, glucose tolerance test, insulin

\section{INTRODUCTION}

Insulin is an anabolic hormone that suppresses gluconeogenesis, protein degradation, and lipolysis as well as stimulates glucose uptake by insulin-dependent tissues (Hayirli, 2006; De Koster and Opsomer, 2013). In early lactation, it is well recognized that a homeorhetic mechanism occurs to favor glucose uptake by the insulin-independent mammary gland through a transient state of insulin resistance (De Koster and Opsomer, 2013). This is coupled with a decrease in insulin synthesis by the pancreas in early lactation (Zachut et al., 2013). In addition, some authors have reported that low plasma insulin concentration was associated with higher milk yield in early postpartum cows (Gärtner et al., 2019; Zinicola and Bicalho, 2019). In response to this situation, protein degradation and lipolysis from body stores are stimulated to get alternative fuel sources for insulin-dependent tissues (McArt et al., 2013). Hence, it is normal, up to a certain point, that plasma nonesterified fatty acid (FA) concentration augments in early lactation in response to the increased lipolysis. However, if an excessive quantity of nonesterified FA reaches the liver to be oxidized, it can have deleterious health effects for the cows by impairing liver functions (Goff and Horst, 1997), which could in turn lead to increased plasma BHB concentration (McArt et al., 2013). Recent efforts have been made to study potential factors contributing to excessive insulin resistance and lipolysis (Mann et al., 2016; Jaakson et al., 2018).

In humans, there is growing evidence that folic acid supplementation, alone or combined with vitamin $\mathrm{B}_{12}$, has a positive effect on insulin resistance, even though a meta-analysis showed wide variations among tri- 
als (Lind et al., 2019). Moreover, other studies have revealed a negative association between vitamin $B_{12}$ status in obese people and insulin resistance (Ho et al., 2014; Cigerli et al., 2016). In cattle, overconditioned cows before calving were also more susceptible to insulin metabolism dysfunction (De Koster et al., 2015; Karis et al., 2020). It has been observed that biotin supplementation has a positive effect on insulin resistance in rats (Sasaki et al., 2012; Aguilera-Mendez et al., 2018). In dairy cows, a supplementation of folic acid and vitamin $\mathrm{B}_{12}$ around parturition has been associated with a positive change in energy partitioning, either by increasing milk production or ECM with no change in DMI and plasma nonesterified FA concentration (Preynat et al., 2009; Gagnon et al., 2015), or by decreasing plasma nonesterified FA and increasing plasma glucose and insulin concentrations without effect on DMI and milk yield (Duplessis et al., 2017). To our knowledge, Duplessis et al. (2017) were the first to report the effect of folic acid and vitamin $\mathrm{B}_{12}$ supplementation on plasma insulin concentration in dairy cows. They concluded that the combined supplement led to a better energy status in early lactation, but further research was needed to study the effect of those vitamins on insulin sensitivity as observed in humans and rats. Thereafter, Girard et al. (2019) found that a supplement of folic acid and vitamin $\mathrm{B}_{12}$ in feed-restricted lactating cows improved insulin sensitivity as suggested by the lower insulin release to elicit the same glucose response after an intravenous glucose tolerance test (IVGTT). Nevertheless, treatment administration in this latter experiment began at about 45 DIM, and the authors used feed restriction to mimic negative energy balance in early lactation. Hence, the effect of this vitamin supplement given before calving until the beginning of the lactation on early postpartum insulin sensitivity is still missing. It could be hypothesized that, given previous results discussed above, insulin sensitivity in early-lactation cows would be improved by supplements of biotin, folic acid, and vitamin $\mathrm{B}_{12}$. The objective of this study was to assess glucose and insulin metabolism in early lactation by using IVGTT for cows receiving a supplement of biotin alone or combined with folic acid plus vitamin $\mathrm{B}_{12}$ given during the transition period.

\section{MATERIALS AND METHODS}

All procedures on animals during the experimentation were previously approved by the Institutional Committee for Animal Care of the Sherbrooke Research and Development Centre and were conducted according to the code of practice of the National Farm Animal Care Council (2009) and the guidelines of the Canadian Council on Animal Care (2009).

\section{Cows, Treatments, and Management}

A total of 32 nonlactating pregnant Holstein cows from the dairy herd at Agriculture and Agri-Food Canada Research Centre (Sherbrooke, QC, Canada) were enrolled in this experiment. Inclusion criteria comprise that cows should have at least 2 parities after their upcoming calving, be of Holstein breed, and have a previous 305-d milk yield greater than 9,500 kg. According to a $2 \times 2$ factorial arrangement, they were blocked according to their previous $305-\mathrm{d}$ milk production into 9-randomized incomplete blocks. Within each block, cows were randomly assigned to 1 of the following levels of biotin supplement: (1) no biotin supplement $\left(\mathbf{B}_{\mathbf{8}}-\right)$ or (2) $20 \mathrm{mg} / \mathrm{d}$ of dietary biotin $\left(\mathbf{B}_{\mathbf{8}}+\right)$. Within each level of biotin, the cows received either (1) $2-\mathrm{mL}$ weekly intramuscular injections of saline $0.9 \% \mathrm{NaCl}$ $\left(\mathbf{B}_{9} \mathbf{B}_{12}-\right)$ or (2) $2.6 \mathrm{~g} / \mathrm{d}$ of dietary folic acid and 2-mL weekly intramuscular injections of $10 \mathrm{mg}$ of vitamin $\mathrm{B}_{12}\left(\mathbf{B}_{9} \mathbf{B}_{12}+\right)$. Treatment doses and administration modes were determined according to previous experiments (Graulet et al., 2007; Girard and Desrochers, 2010; Duplessis et al., 2017). Dietary treatments of biotin and folic acid were unprotected from the ruminal degradation and given before the morning meal and after orts removal to ensure its entire consumption with $200 \mathrm{~g}$ of fine-ground corn and approximately 100 $\mathrm{g}$ of corn silage. Saline and vitamin $\mathrm{B}_{12}$ injections were given each Friday at $1400 \mathrm{~h}$. Treatments were aimed to begin at least $21 \mathrm{~d}$ before the expected calving date and were given until 28 DIM. After calving, 14 cows were in second, 8 in third, 4 in fourth, 5 in fifth, and 1 in sixth lactation. Cows were housed in tiestalls under $17 \mathrm{~h}$ of light per day and milked twice daily at 12 -h intervals.

Close-up ration was served as TMR, beginning 28 d before the expected calving date at 0800 and 1300 h. After calving, early-lactation TMR was given once daily at $0800 \mathrm{~h}$ and pushed toward cows 4 times per day. Rations were formulated from NDS Professional software (RUM and N Sas, Reggio Emilia, Italy) based on the requirements of the Cornell Net Carbohydrate and Protein System software (CNCPS version 6.5/6.55; Cornell University, Ithaca, NY). The close-up ration had on average $26.9 \%$ of hay, $7.8 \%$ of grass and legume silage, $42.3 \%$ of corn silage, $10.4 \%$ of soybean meal, $10.0 \%$ of beet pulp, $1.3 \%$ of mineral and vitamin premix, $1.0 \%$ of limestone, and $0.4 \%$ of urea containing $13.7,22.8,39.0$, and $40.4 \%$ of $\mathrm{CP}$, ADF, NDF with inclusion of heat-stable $\alpha$-amylase in the analysis, and NFC on a DM basis, respectively, and $1.52 \mathrm{Mcal} / \mathrm{kg}$ of $\mathrm{NE}_{\mathrm{L}}$ of DM. The early-lactation ration had on average $3.1 \%$ of grass hay, $28.3 \%$ of grass and legume silage, $28.2 \%$ of corn silage, $22.4 \%$ of cracked corn, $7.1 \%$ of soybean meal, $2.8 \%$ of beet pulp, $1.8 \%$ of corn distiller 
grain, $1.8 \%$ of corn gluten meal, $1.2 \%$ of canola meal, $1.2 \%$ of micronized soybean, $1.7 \%$ of mineral and vitamin premix, and $0.8 \%$ of limestone containing 17.1, 17.4, 29.3, and $45.9 \%$ of $\mathrm{CP}, \mathrm{ADF}, \mathrm{NDF}$ with inclusion of heat-stable $\alpha$-amylase in the analysis, and NFC on a DM basis, respectively, and $1.64 \mathrm{Mcal} / \mathrm{kg}$ of $\mathrm{NE}_{\mathrm{L}}$ of DM. Feed sampling and analyses were described by Duplessis and Girard (2019). Dry matter content of forages was evaluated twice per week (Agri-Analyze Agricultural Laboratory, Sherbrooke, QC, Canada) to adjust the ration if needed, allowing $10 \%$ of refusals. Water consumption was ad libitum.

\section{Data Collection, Calculations, and Analyses}

$D M I, B W, B C S$, and Energy Balance. Quantity of TMR served and orts were weighed every day for 7 d before performing the IVGTT. Daily DMI was then calculated by subtracting quantity fed minus refusals multiplied by DM content of the TMR. Cow BW was taken from 2 consecutive days, $4 \mathrm{~d}$ after the beginning of treatments, and -2 and $-1 \mathrm{~d}$ relative to the IVGTT. Body condition score was taken by the same individual at enrollment and the day of the IVGTT according to a 1-to-5 scale with quarter points (Ferguson et al., 1994). Energy balance (EB) was computed using data from 7 d before the IVGTT according to the NRC (2001) as follows:

$$
\begin{aligned}
\mathrm{EB}(\mathrm{Mcal} / \mathrm{d}) & =\left[\mathrm{DMI}(\mathrm{kg} / \mathrm{d}) \times \operatorname{diet~} \mathrm{NE}_{\mathrm{L}}(\mathrm{Mcal} / \mathrm{kg})\right] \\
-\{[0.08 & \left.\times \mathrm{BW}^{0.75}(\mathrm{~kg})\right]+[\text { milk yield }(\mathrm{kg}) \\
& \left.\left.\times \operatorname{milk~} \mathrm{NE}_{\mathrm{L}}(\mathrm{Mcal} / \mathrm{kg})\right]\right\}
\end{aligned}
$$

and

$$
\begin{gathered}
\mathrm{EB}(\% \text { of required energy })=[\mathrm{DMI}(\mathrm{kg} / \mathrm{d}) \\
\left.\times \operatorname{diet~} \mathrm{NE}_{\mathrm{L}}(\mathrm{Mcal} / \mathrm{kg})\right] /\left\{\left[0.08 \times \mathrm{BW}^{0.75}(\mathrm{~kg})\right]\right. \\
\left.+\left[\text { milk yield }(\mathrm{kg}) \times \text { milk } \mathrm{NE}_{\mathrm{L}}(\mathrm{Mcal} / \mathrm{kg})\right]\right\} \times 100
\end{gathered}
$$

Milk $\mathrm{NE}_{\mathrm{L}}$ was computed as follows (NRC, 2001):

$$
\begin{aligned}
& \text { Milk } \mathrm{NE}_{\mathrm{L}}(\mathrm{Mcal} / \mathrm{kg})=0.0929 \times \text { milk fat }(\%) \\
& +0.0547 \times \text { milk protein }(\%)+0.0395 \\
& \times \text { milk lactose }(\%)
\end{aligned}
$$

Milk Yield and Components. Milk yield was recorded at each milking $7 \mathrm{~d}$ before performing the IVGTT. Milk samples with bronopol preservative for component analyses were taken from 2 consecutives milkings, -4 and $-3 \mathrm{~d}$ relative to the IVGTT. These samples were immediately sent to the Lactanet labora- tory (Sainte-Anne-de-Bellevue, QC, Canada) for milk fat, protein, and lactose concentration determination by mid-infrared reflectance spectrometry (MilkoScan FT 6000, Foss, Hillerød, Denmark).

Blood Samples. Blood samples by caudal venipuncture were taken $-7 \mathrm{~d}$ relative to the IVGTT using a Vacutainer system (Becton, Dickinson and Co., Franklin Lakes, NJ) at 1315 h, approximately $5 \mathrm{~h}$ after the morning meal, but before vitamin $\mathrm{B}_{12}$ injections. A blood sample was also taken $5 \mathrm{~h}$ after the end of the intravenous glucose infusion and $3 \mathrm{~h}$ after the meal on the day of the IVGTT. Tubes with EDTA were used for plasma biotin, folates, vitamin $\mathrm{B}_{12}$, nonesterified $\mathrm{FA}$, and BHB concentration analyses, whereas heparinized tubes were used for plasma glucose, insulin, methylmalonic acid (MMA) and sulfur AA concentration analyses. Tubes were centrifuged within 30 min of collection at $2,400 \times g$ and $4^{\circ} \mathrm{C}$ for $15 \mathrm{~min}$. Samples were stored at $-20^{\circ} \mathrm{C}$ until analysis, except for tubes for MMA and AA analyses; these were stored at $-80^{\circ} \mathrm{C}$. Regarding sulfur AA analysis, $1.0 \mathrm{~g}$ of plasma was weighed with $0.2 \mathrm{~g}$ of an internal standard of AA labeled with stable isotopes (CDN Isotopes Inc., Montréal, QC, Canada and Cambridge Isotope Laboratories Inc., Andover, MA) as described by Doepel and Lapierre (2010). Plasma concentration of biotin was analyzed in duplicate following the manufacturer instructions (IDK Biotin ELISA, Immundiagnostik AG, Bensheim, Germany). Plasma folate and vitamin $\mathrm{B}_{12}$ concentrations were determined in duplicate by radioassay using a commercial kit (SimulTRAC B B $/$ FOLATE-S, MP Biomedicals, Solon, $\mathrm{OH})$. The interassay coefficients of variation were $2.3,3.9$, and $3.7 \%$ for biotin, folate, and vitamin $\mathrm{B}_{12}$ analyses, respectively. Commercial kits were used for plasma nonesterified FA [HR Series NEFA-HR(2), Wako Chemicals USA Inc., Richmond, VA], BHB ( $\beta$-hydroxybutyrate reagent set, Pointe Scientific Inc., Canton, MI), glucose [Glucose (Tinder) assay, Genzyme Diagnostics PEI Inc., Charlottetown, PE, Canada], and insulin (Mercodia Bovine Insulin ELISA, Mercodia AB, Uppsala, Sweden) concentration analyses. Plasma sulfur AA and MMA concentrations were analyzed using a GC-MS in ionization mode (model CG7890BMSHunter 5977A, Agilent Technologies, Santa Clara, CA) as described by Duplessis et al. (2017). Plasma concentrations of biotin, folates, vitamin $\mathrm{B}_{12}$, MMA, and sulfur AA were only analyzed at $-7 \mathrm{~d}$ relative to the IVGTT.

Intravenous Glucose Tolerance Test. The day before performing the IVGTT, an Angiocath catheter (14 gauge $\times 8.26 \mathrm{~cm}$; Becton, Dickinson and Co.) was inserted into one jugular vein to infuse glucose and a catheter into the other one to take blood samples. Feed was withdrawn $12 \mathrm{~h}$ before the IVGTT, but cows still 
had free access to water. The IVGTT was performed after the morning milking. A dose of $0.3 \mathrm{~g}$ of dextrose $/ \mathrm{kg}$ of $\mathrm{BW}$ was administered in $7.6(\mathrm{SD}=1.8) \mathrm{min}$. Blood samples were taken at $-20,-10$ (baseline), 2, 5, 10, $15,20,25,30,40,50,60,80,100$, and 120 min relative to the end of the intravenous glucose infusion. Blood samples were handled as described in the previous section. All samples were analyzed for plasma concentrations of glucose, insulin, and nonesterified FA. In addition, baseline samples were also analyzed for plasma BHB and glucagon concentrations. A commercial RIA kit was used to analyze plasma glucagon concentration (Glucagon RIA kit, EMD Millipore corp., St. Charles, MO). The same commercial kits as described in the previous section were used for the other metabolites. The morning meal was given after the last blood sampling of the IVGTT.

Positive incremental areas under the curve (AUC) for plasma glucose and insulin concentrations were calculated as per Cardoso et al. (2011) and corrected for baseline concentrations. Glucose clearance rate (CR) was calculated according to Kerestes et al. (2009) as follows: [(ln plasma glucose at time point $2-\ln$ plasma glucose at time point 60$) /($ time point 60 - time point $2)] \times 100$ as percent per minute. Insulin CR was computed as described by Mann et al. (2016) as follows: [(ln plasma insulin at peak time point - ln plasma insulin at time point 60$) / 60-$ peak time point] $\times 100$ as percent per minute. Times to glucose and insulin half-life were obtained by the following equation: $\ln (2) /$ glucose or insulin CR as min (Kerestes et al., 2009). Maximal plasma glucose and insulin concentrations, time to reach maximal insulin concentration, as well as minimum plasma nonesterified FA concentration were the values observed for each cow.

\section{Statistical Analyses}

Daily data of DMI, EB, and milk yield the week before the IVGTT were averaged to get 1 record per cow. Body weight data from the 2 consecutive days were also averaged. Data at enrollment, DMI, EB, BW, BCS, milk yield and components, and plasma concentrations of metabolites from blood sampling $7 \mathrm{~d}$ before the IVGTT were analyzed using Proc MIXED of SAS (version 9.4; SAS Institute, 2012) according to a $2 \times 2$ factorial arrangement [2 levels of biotin supplementation $\left(\mathrm{B}_{8}-\right.$ or $\left.\mathrm{B}_{8}+\right)$ and 2 levels of folic acid and vitamin $\mathrm{B}_{12}$ supplementation $\left(\mathrm{B}_{9} \mathrm{~B}_{12}-\right.$ or $\left.\mathrm{B}_{9} \mathrm{~B}_{12}+\right)$ ] in a 9 -incomplete block design. According to the factorial arrangement used, the treatment was decomposed in biotin, folic acid combined with vitamin $\mathrm{B}_{12}$ and the interaction biotin $\times$ folic acid combined with vitamin $\mathrm{B}_{12}$ effects. The Bayesian information criterion was smaller when block was a fixed effect compared with a random effect. The same model was used for analyzing data at enrollment. Residuals were visually assessed for normality and homoscedasticity. Plasma concentrations of insulin and BHB violated the normality assumption and data were log-transformed. Results were then back transformed and presented as geometric means and $95 \%$ confidence intervals when specified. Otherwise, results were presented as least squares means and standard errors of the mean.

Data from the 2 baseline blood samplings before intravenous glucose infusion were averaged per cow. Proc MIXED of SAS was used with the same fixed effects described above to evaluate if baseline metabolites were different among treatments. Maximal plasma glucose and insulin concentrations, minimal plasma nonesterified FA concentration, glucose and insulin AUC and $\mathrm{CR}$, time to glucose and insulin half-life, time to reach maximal insulin concentration, and time to reach nonesterified FA nadir were also analyzed with Proc MIXED as dependent variables. When needed to respect the normality assumption, data were log-transformed and processed as described above. Results were considered significant when $P \leq 0.05$, and as a tendency at $0.05<$ $P \leq 0.10$. The SLICE option of the LSMEANS statement performing an $F$ test was used when the interaction reached significance or was a tendency to help interpret the results. We used Proc MEANS of SAS to get averages of metabolites that were not normally distributed, and results are presented as means followed by standard deviation in the text.

\section{RESULTS}

Treatments began $26.8 \pm 2.1 \mathrm{~d}$ before the parturition ( $P \geq 0.17$; Table 1). Previous 305-d lactation milk yield averaged $10,957 \pm 154 \mathrm{~kg}$ and did not differ among treatments $(P \geq 0.60)$. At enrollment, BCS was not different among treatments $(P \geq 0.19)$, but BW was greater by $57 \mathrm{~kg}$ for cows receiving the biotin supplement $4 \mathrm{~d}$ following treatment commencement $(P$ $=0.02$; Table 1 ). Two cows were excluded at calving in the treatment $\mathrm{B}_{8}+\mathrm{B}_{9} \mathrm{~B}_{12}-$ due to calving problems unrelated to the treatment. The IVGTT was performed on average at $24.9 \pm 0.9 \mathrm{DIM}(P \geq 0.16)$.

\section{Production Performance and Plasma Metabolites the Week Before the IVGTT}

Dry matter intake and BW did not differ among treatments $(P>0.25$; Table 2$)$ and averaged $25.0 \pm$ $1.1 \mathrm{~kg} / \mathrm{d}$ and $672.1 \pm 26.4 \mathrm{~kg}$, respectively. Body condition score was slightly greater for $\mathrm{B}_{8}+$ cows $(2.65$ $\pm 0.08)$ than $\mathrm{B}_{8}-$ cows $(2.42 \pm 0.07 ; P=0.05)$. For 


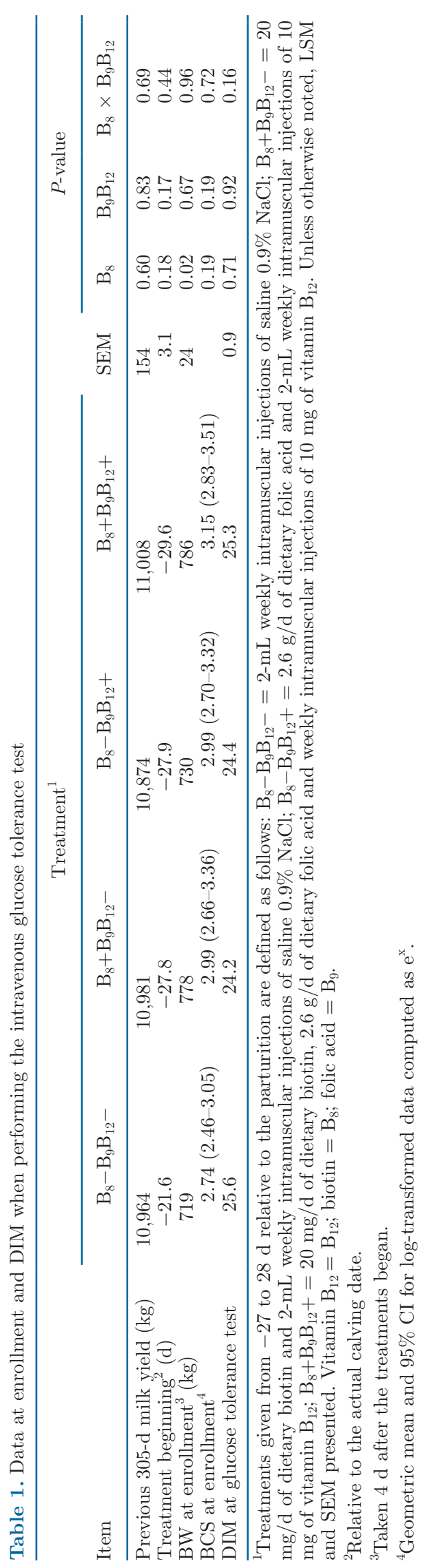

$\mathrm{B}_{9} \mathrm{~B}_{12}-$ cows, there was a tendency for $\mathrm{B}_{8}+$ cows to have lower $\mathrm{EB}$ as percentage of requirements compared with $\mathrm{B}_{8}-$ cows $(P=0.09)$, whereas there was no effect for $\mathrm{B}_{9} \mathrm{~B}_{12}+$ cows $\left(P=0.45 ; \mathrm{B}_{8} \times \mathrm{B}_{9} \mathrm{~B}_{12}\right.$ interaction, $P=$ 0.08). However, when considering EB as Mcal/d, there was no treatment effect observed. No treatment effect was noted regarding milk and component yields and milk fat and protein concentrations $(P \geq 0.15$; Table $2)$. Milk lactose concentration tended to be slightly lower for $\mathrm{B}_{9} \mathrm{~B}_{12}+$ cows $(P=0.06)$.

As expected, plasma concentrations of biotin, folates, and vitamin $\mathrm{B}_{12}$ were increased by their respective supplementation $(P<0.002)$. For $\mathrm{B}_{9} \mathrm{~B}_{12}+$ cows, plasma concentration of vitamin $\mathrm{B}_{12}$ was higher for $\mathrm{B}_{8}+$ cows than compared with $\mathrm{B}_{8}-$ cows $(P=0.02)$, whereas there was no difference in $\mathrm{B}_{9} \mathrm{~B}_{12}-$ group $\left(P=0.60 ; \mathrm{B}_{8}\right.$ $\times \mathrm{B}_{9} \mathrm{~B}_{12}$ interaction, $\left.P=0.05\right)$. No treatment effect was noted on plasma concentrations of MMA, glucose, nonesterified FA, BHB, Met, and Cys the week before conducting the IVGTT (Table 2). However, plasma insulin concentration tended to be greater by $2.3 \mu \mathrm{U} /$ $\mathrm{mL}$ for cows receiving the biotin supplement compared with cows who did not $(P=0.08)$. Plasma concentration of Hcy was greater for cows receiving folic acid and vitamin $\mathrm{B}_{12}$ supplementation than cows who did not when no biotin was fed $(P=0.006)$, whereas there was no effect when cows received the biotin supplement $(P$ $=0.77 ; \mathrm{B}_{8} \times \mathrm{B}_{9} \mathrm{~B}_{12}$ interaction, $\left.P=0.08\right)$.

\section{The IVGTT}

At baseline, plasma glucagon, glucose, and nonesterified FA concentrations did not differ among treatments, and averaged $112.7 \pm 12.0 \mathrm{pg} / \mathrm{mL}, 2.95 \pm 0.21 \mathrm{mM}$, and $1,392.4 \pm 160.8 \mu M$, respectively $(P \geq 0.19$; Table $3)$. There was a trend for a $\mathrm{B}_{8} \times \mathrm{B}_{9} \mathrm{~B}_{12}$ interaction $(P$ $=0.10$ ) regarding baseline plasma BHB concentration. Indeed, there was a tendency for $\mathrm{B}_{8}+$ cows to have lower baseline plasma $\mathrm{BHB}$ concentration with $\mathrm{B}_{9} \mathrm{~B}_{12}+$ cows compared with $\mathrm{B}_{9} \mathrm{~B}_{12}-$ cows $(P=0.07)$, whereas there was no treatment effect for $\mathrm{B}_{8}-$ cows $(P=0.67)$. Regarding baseline plasma insulin concentration for $\mathrm{B}_{9} \mathrm{~B}_{12}+$ cows, the concentration was $45 \%$ higher for $\mathrm{B}_{8}+$ cows compared with $\mathrm{B}_{8}-$ cows $(P=0.007)$, whereas no difference was noted for $\mathrm{B}_{9} \mathrm{~B}_{12}-$ cows $\left(P=0.93 ; \mathrm{B}_{8} \times\right.$ $\mathrm{B}_{9} \mathrm{~B}_{12}$ interaction, $P=0.05$ ).

Neither time to half-maximal concentration, nor AUC nor CR of glucose was different among treatments $(P \geq 0.57$; Table 3 and Figure $1 \mathrm{~A})$. For $\mathrm{B}_{9} \mathrm{~B}_{12}+$ cows, maximal concentration of glucose was greater in $\mathrm{B}_{8}+$ $(P=0.01)$, although no treatment effect was observed in $\mathrm{B}_{9} \mathrm{~B}_{12}-$ cows $\left(P=0.69 ; \mathrm{B}_{8} \times \mathrm{B}_{9} \mathrm{~B}_{12}\right.$ interaction, $P=$ $0.05)$. The biotin supplementation increased maximal insulin concentration and $\mathrm{AUC}$ by $15.5 \mu \mathrm{U} / \mathrm{mL}$ and 830 
Duplessis and Girard: BIOTIN, FOLIC ACID, AND VITAMIN B ${ }_{12}$ SUPPLEMENTS

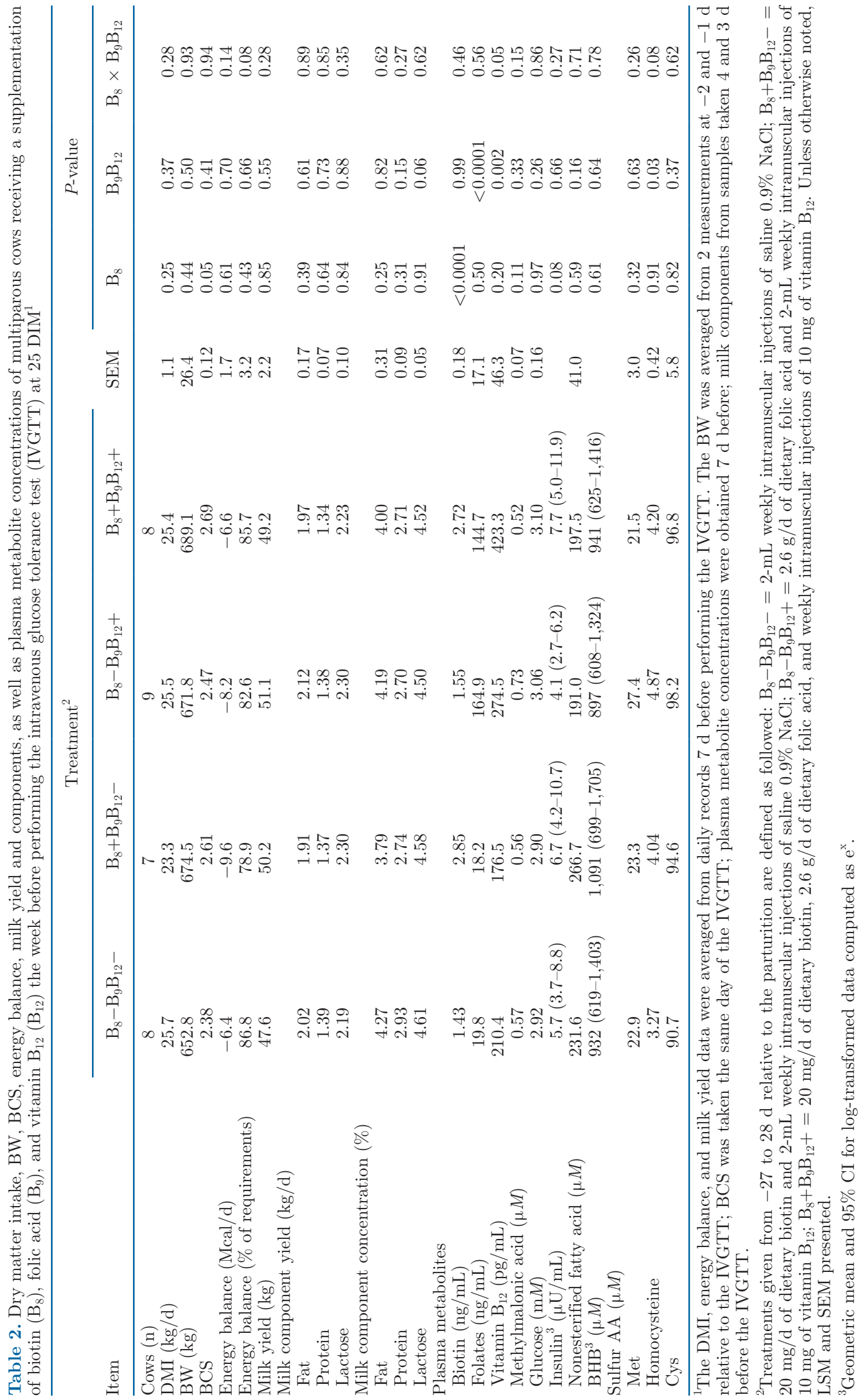




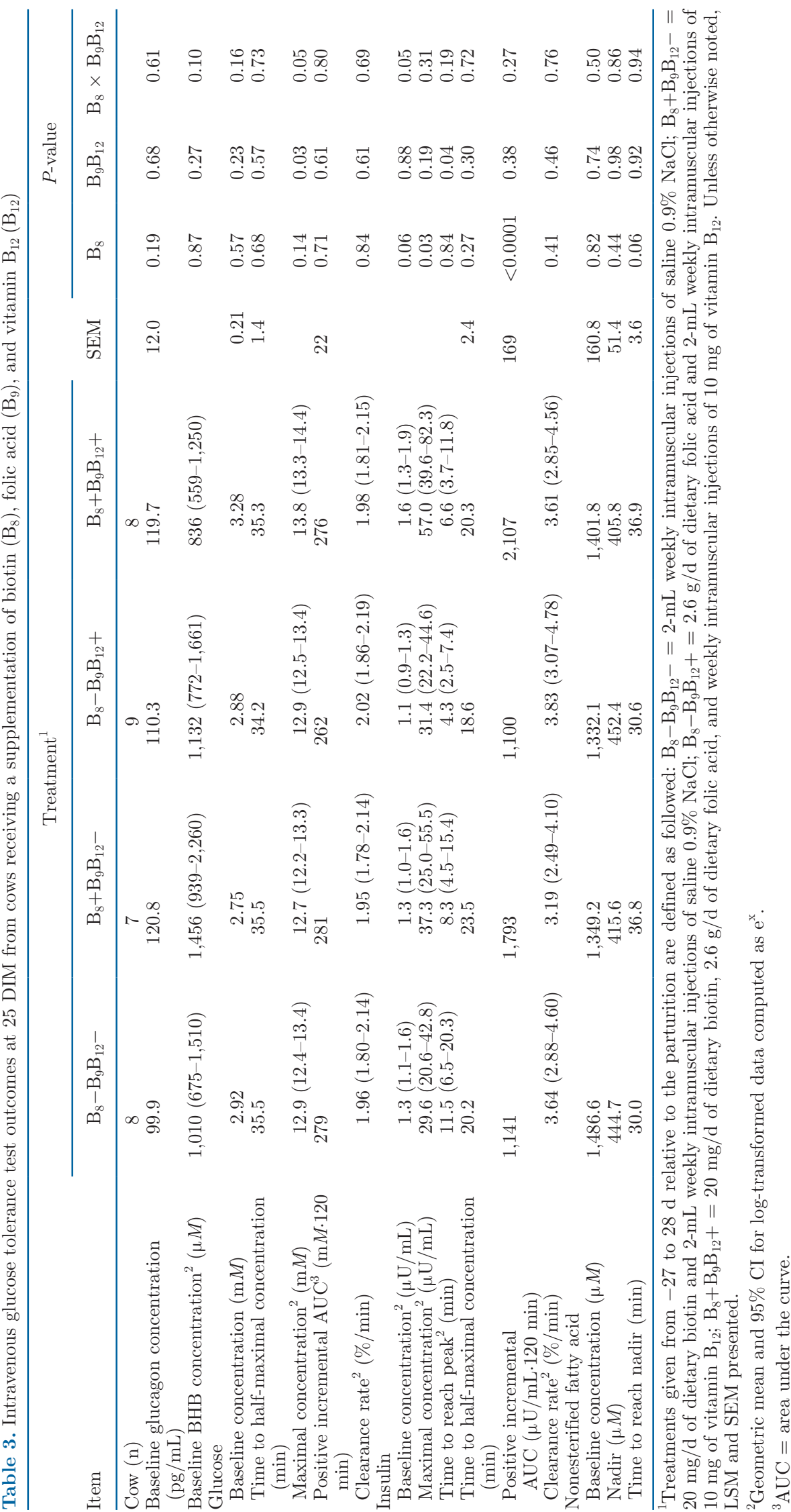


$\mathrm{m} M \cdot 120$ min, respectively $(P \leq 0.03$; Table 3 and Figure 1B). Neither time to half-maximal insulin concentration nor insulin $\mathrm{CR}$ was different among treatments $(P \geq 0.27)$, and averaged $20.7 \pm 2.4 \mathrm{~min}$ and $3.76(\mathrm{SD}$ $=1.24) \% / \mathrm{min}$, respectively. Insulin peak was reached earlier for $\mathrm{B}_{9} \mathrm{~B}_{12}+$ cows compared with $\mathrm{B}_{9} \mathrm{~B}_{12}-$ cows $(P$ $=0.04)$. Nonesterified FA concentration nadir tended to be reached later for $\mathrm{B}_{8}+$ cows, regardless of the $\mathrm{B}_{9} \mathrm{~B}_{12}$ supplementation $(P=0.06$; Table 3 and Figure $1 \mathrm{C})$, but the lowest plasma nonesterified FA concentration was not different according to treatments $(P \geq 0.44)$.

\section{Plasma Metabolite Recovery After the IVGTT}

Blood samples were taken $5 \mathrm{~h}$ after the intravenous glucose infusion and $3 \mathrm{~h}$ after the meal distribution to evaluate how plasma metabolites recovered from the IVGTT among treatments. For $\mathrm{B}_{9} \mathrm{~B}_{12}-$ cows, plasma concentrations of glucose and $\mathrm{BHB}$ were respectively lower and greater for $\mathrm{B}_{8}+$ cows compared with $\mathrm{B}_{8}-$ cows $(P \leq 0.02)$, whereas no effect was observed with $\mathrm{B}_{9} \mathrm{~B}_{12}+\left(P \geq 0.13 ; \mathrm{B}_{8} \times \mathrm{B}_{9} \mathrm{~B}_{12}\right.$ interaction, $P \leq 0.007$; Table 4). Plasma insulin and nonesterified FA concentrations were not different among treatments $(P \geq$ $0.24)$.

\section{DISCUSSION}

It is noteworthy that milk production performance and plasma metabolite concentrations for the same cows within the first 3 wk of lactation were presented elsewhere (Duplessis et al., 2019). Briefly, milk yield was about $14 \%$ greater for $\mathrm{B}_{9} \mathrm{~B}_{12}+$ cows compared with $\mathrm{B}_{9} \mathrm{~B}_{12}-$ cows among $\mathrm{B}_{8}-$ cows, whereas no difference was noted for $\mathrm{B}_{8}+$ cows. According to the current results, the week before performing the IVGTT (i.e., 18-24 DIM), milk yield was not statistically different among treatments. It seems that the positive effect of the $\mathrm{B}_{9} \mathrm{~B}_{12}+$ treatment lessened as lactation progressed. Within the first 3 wk of lactation, BCS was not different among treatments. However, in $\mathrm{B}_{8}-$ group, postpartum plasma nonesterified FA and BW loss were greater for $\mathrm{B}_{9} \mathrm{~B}_{12}+$ cows than $\mathrm{B}_{9} \mathrm{~B}_{12}-$ cows, whereas there was no effect in $\mathrm{B}_{8}+$ group (Duplessis et al., 2019). Nevertheless, plasma concentration of BHB was not different among treatments, suggesting that the body reserve mobilization was not excessive.

As commonly observed in the literature (Graulet et al., 2007; Girard and Desrochers, 2010; Duplessis et al., 2017), plasma vitamin concentrations were increased by their respective supplements in the current study. Duplessis et al. (2019) also reported that plasma concentrations of those vitamins were increased by their respective supplement from -3 to 3 wk relative to the
A
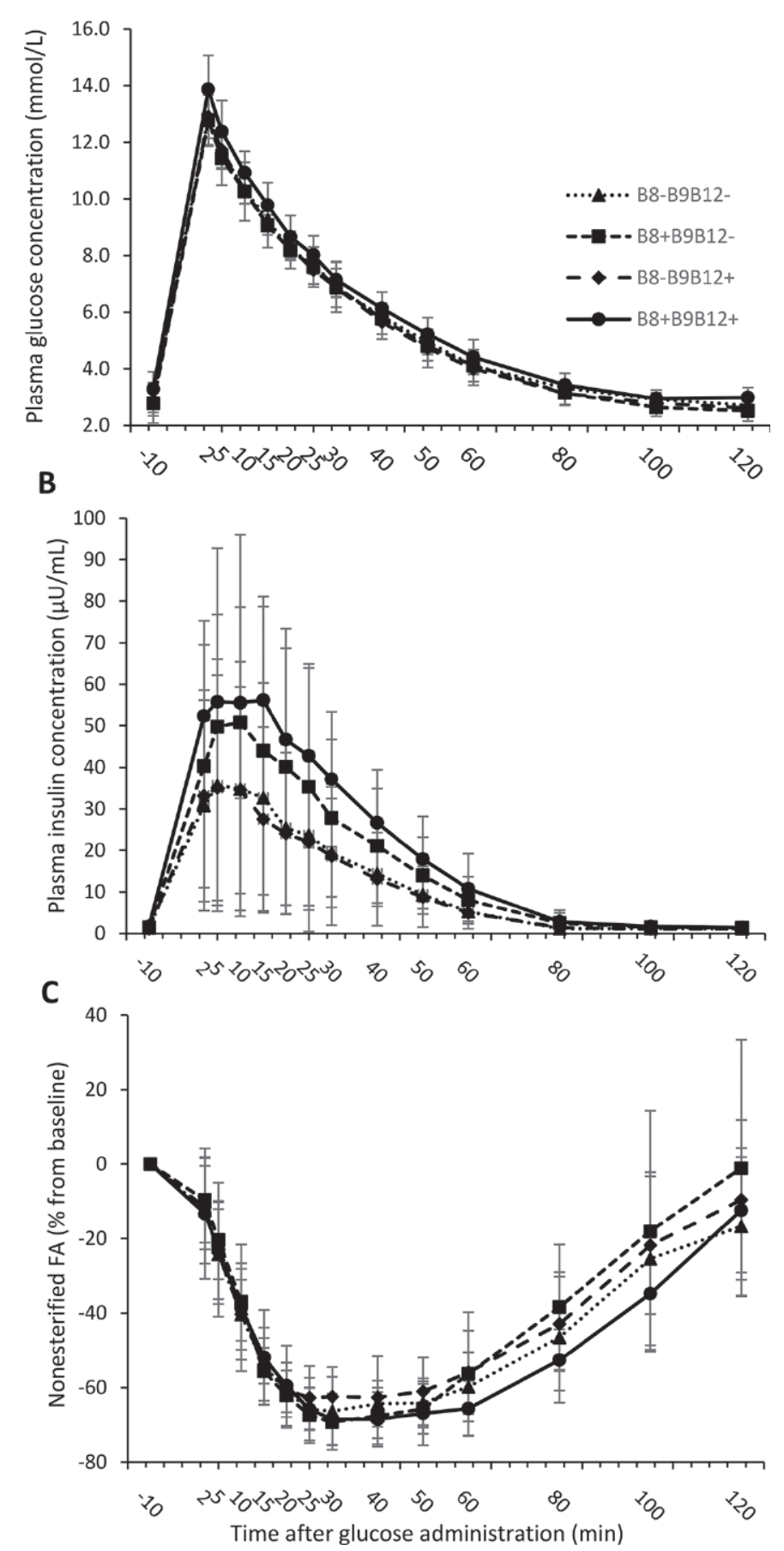

Figure 1. Plasma concentrations of glucose (A), insulin (B), and percentage of nonesterified fatty acid from baseline $(\mathrm{C})$ after the intravenous glucose administration at 25 DIM. Treatments given from -27 to 28 d relative to the parturition are defined as followed: $\mathrm{B}_{8}-$ $\mathrm{B}_{9} \mathrm{~B}_{12}-=2-\mathrm{mL}$ weekly intramuscular injections of saline $0.9 \% \mathrm{NaCl}$; $\mathrm{B}_{8}+\mathrm{B}_{9} \mathrm{~B}_{12}-=20 \mathrm{mg} / \mathrm{d}$ of dietary biotin and $2-\mathrm{mL}$ weekly intramuscular injections of saline $0.9 \% \mathrm{NaCl} ; \mathrm{B}_{8}-\mathrm{B}_{9} \mathrm{~B}_{12}+=2.6 \mathrm{~g} / \mathrm{d}$ of dietary folic acid and 2-mL weekly intramuscular injections of $10 \mathrm{mg}$ of vitamin $\mathrm{B}_{12} ; \mathrm{B}_{8}+\mathrm{B}_{9} \mathrm{~B}_{12}+: 20 \mathrm{mg} / \mathrm{d}$ of dietary biotin, $2.6 \mathrm{~g} / \mathrm{d}$ of dietary folic acid, and weekly intramuscular injections of $10 \mathrm{mg}$ of vitamin $\mathrm{B}_{12}$. Error bars represent SEM. 
Duplessis and Girard: BIOTIN, FOLIC ACID, AND VITAMIN B ${ }_{12}$ SUPPLEMENTS

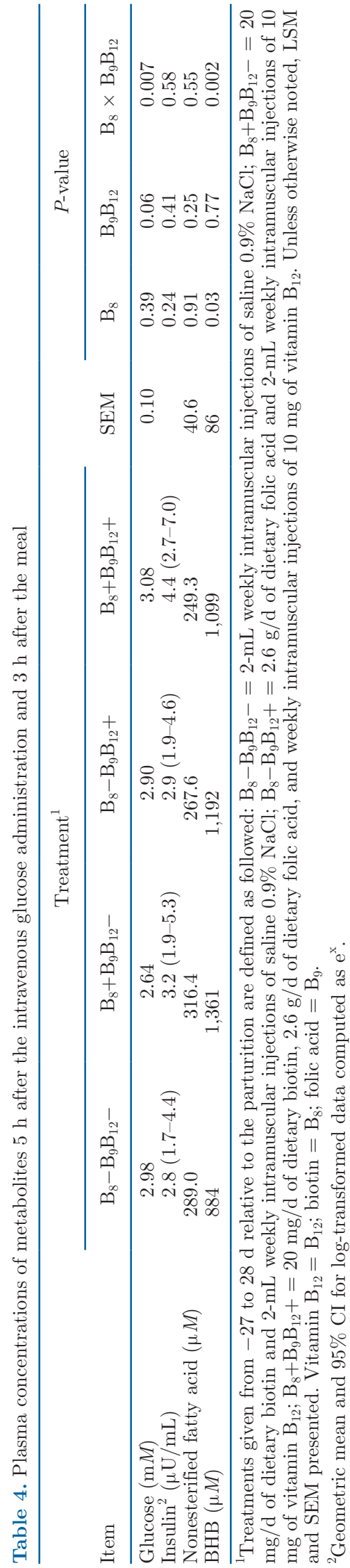

calving of the same cows. The greater increase in plasma folate concentration in the current study when cows received dietary folic acid supplement compared with results from Graulet et al. (2007) could be explained by the blood sampling time relative to the ingestion of the supplement; which was before and $5 \mathrm{~h}$ after the supplementation in Graulet et al. (2007) and the current study, respectively. It has been previously shown that plasma folate concentration increases rapidly after a dietary folate supplementation (Girard et al., 1992). Plasma vitamin $\mathrm{B}_{12}$ concentration was greater for $\mathrm{B}_{8}+\mathrm{B}_{9} \mathrm{~B}_{12}+$ cows compared with $\mathrm{B}_{8}-\mathrm{B}_{9} \mathrm{~B}_{12}+$ cows. This suggests that the addition of biotin probably modified the use of vitamin $B_{12}$ by the cells when cows also received folic acid and vitamin $\mathrm{B}_{12}$ supplements. However, this condition was not translated into greater plasma MMA concentration, implying that the possible decreased cellular utilization of vitamin $\mathrm{B}_{12}$ did not interfere with the activity of the methylmalonyl-CoA mutase.

Before performing the IVGTT, baseline plasma concentrations of glucose and insulin in the current study were lower than previously reported by Mann et al. (2016) and Jaakson et al. (2018) in early-lactation cows. This could partially be explained by the longer duration of feed deprivation before baseline blood sampling in the current study (Schoenberg et al., 2012). A metaanalysis by Lind et al. (2019) reported that there is some evidence that a supplementation of folic acid, alone or combined with vitamin $\mathrm{B}_{12}$, lowered insulin resistance in humans. This effect is not well understood, but some speculations could be made. One hypothesis underlined by Lind et al. (2019) that possibly explains the effect of a folic acid supplementation on insulin resistance is the link between this vitamin and homocysteine. Folates are closely involved with vitamin $\mathrm{B}_{12}$ in the methylation pathway (McFadden et al., 2020). The methylated form of folates, 5-methyl-tetrahydrofolate, can give its methyl group to homocysteine to form Met, requiring vitamin $\mathrm{B}_{12}$ as a coenzyme. Met could then be used for protein synthesis or transformed into S-adenosylmethionine. The latter is the major methyl donor in mammals. After giving its methyl group, which could be used in several biological methylations, S-adenosylmethionine is converted into S-adenosylhomocysteine and then reversibly hydrolyzed to homocysteine. Afterward, homocysteine could either be remethylated again in Met or enter into the transsulfuration pathway (McFadden et al., 2020). Hence, folates are required to maintain normal blood homocysteine concentration (Combs and McClung, 2017), and homocysteine has been suggested to have a deleterious effect on insulin sensitivity (Lind et al., 2019). Nevertheless, in the current study, plasma homocysteine concentration was greater for $\mathrm{B}_{9} \mathrm{~B}_{12}+$ cows compared with $\mathrm{B}_{9} \mathrm{~B}_{12}-$ cows. 
Even though Lind et al. (2019) did not find any additional positive effects of combining folate supplement with vitamin $B_{12}$ on insulin sensitivity, there is growing evidence that serum vitamin $B_{12}$ concentration is inversely associated with glucose metabolism dysfunction in humans at different lifetime stages and conditions (Jayashri et al., 2018; Radzicka et al., 2019). Vitamin $\mathrm{B}_{12}$ is also involved as a coenzyme for methylmalonylCoA mutase in the transformation of propionate, some AA, and odd-chained FA for their entry into the Krebs cycle to provide energy via gluconeogenesis (Combs and McClung, 2017). In ruminants, propionate is the major fuel source for gluconeogenesis. In dairy cows, a supplement of folic acid, alone or combined with vitamin $\mathrm{B}_{12}$, has been reported to change energy partitioning within the first 5 wk of lactation by lowering plasma nonesterified FA and increasing plasma glucose and insulin concentrations despite similar DMI and milk yield among treatments (Duplessis et al., 2017). Other studies have concluded that metabolic efficiency in early-lactation cows was enhanced by the combined supplement of folic acid and vitamin $\mathrm{B}_{12}$ compared with folic acid supplementation alone (Graulet et al., 2007; Preynat et al., 2009). More recently, Girard et al. (2019) observed that feed-restricted cows receiving a supplementation of folic acid and vitamin $B_{12}$ had lower insulin peak and positive incremental AUC when submitted to an IVGTT compared with control cows. Our current results from early-lactation cows did not support these last observations as no $\mathrm{B}_{9} \mathrm{~B}_{12}$ effect was noted on these variables. Nevertheless, time to reach insulin peak was earlier in $\mathrm{B}_{9} \mathrm{~B}_{12}+$ cows compared with $\mathrm{B}_{9} \mathrm{~B}_{12}-$ cows, suggesting an improvement of the insulin response with this vitamin supplement following glucose administration, although this was not translated into enhanced IVGTT outcomes. The same glucose dose was administered in this current study as the study from Girard et al. (2019); the major difference between this last study and the current trial is the stage of lactation when the IVGTT was performed [i.e., at 25 DIM for the current experiment and at 77 DIM after a feed restriction to induce negative EB for the Girard et al. (2019) experiment]. Cows during feed restriction in the trial of Girard et al. (2019) were in a greater state of negative EB by about $12 \mathrm{Mcal} / \mathrm{d}$ than cows in the present study around 18 to 24 DIM. Hence, this was accompanied with greater plasma nonesterified FA and $\mathrm{BHB}$, and lower plasma glucose and insulin concentrations before the IVGTT for cows in the trial of Girard et al. (2019). The discrepancy regarding EB and lactation stage between these 2 studies could explain the different response during the IVGTT for $\mathrm{B}_{9} \mathrm{~B}_{12}+$ cows.

Similar to vitamin $\mathrm{B}_{12}$, biotin is involved in the steps to transform propionate for its entry into the Krebs cy- cle (Combs and McClung, 2017). Indeed, biotin acts as a coenzyme for propionyl-CoA carboxylase. Moreover, biotin is a coenzyme for carboxylases involved in metabolic reactions related to glucose and FA metabolism. It is also the coenzyme for pyruvate carboxylase, which catalyzes the first step of gluconeogenesis. In rat pancreatic islets in culture, Romero-Navarro et al. (1999) found that biotin increased insulin secretion. Moreover, some studies have found that biotin supplementation improved insulin sensitivity in diabetic mice (Reddi et al., 1988) and in rats receiving high-fructose (AguileraMendez et al., 2018) and high-fat (Orhan et al., 2018) diets. Nevertheless, given the major importance of gluconeogenesis in ruminants, glucose metabolism of cows and rats is different. To the best of our knowledge, the current paper is the first to report the effect of a supplement of biotin given around the parturition on insulin resistance measured by IVGTT in dairy cows. In contrary to our results in which plasma insulin concentration was higher when cows received dietary biotin the week before the IVGTT, Zimmerly and Weiss (2001) and Wei et al. (2018) did not find any effect of biotin supplementation on plasma insulin concentration in early lactation. Results from the IVGTT suggested that insulin sensitivity of $\mathrm{B}_{8}+$ cows was reduced. In addition, plasma glucose and BHB concentrations were still disrupted $5 \mathrm{~h}$ after the glucose administration for those cows. Nevertheless, it could not be ruled out that the IVGTT outcomes following biotin supplementation were merely due to a stimulated insulin secretion as observed in vitro in rats (Romero-Navarro et al., 1999). Moreover, De Koster et al. (2015) found that body fat reserve was negatively associated with the insulin response of the glucose metabolism at the end of the dry period. In the current study, cows receiving the biotin supplement had slightly greater BCS and plasma concentration of insulin the week before performing the IVGTT. To verify if this condition could have been a confounding factor, BCS, as a proxy of adiposity recorded on the same day of IVGTT, was added to models as a covariate, but failed to be significant. In opposition to De Koster et al. (2015), it is worthwhile to note that cows in the current study had a normal BCS range for the studied stage of lactation regardless of the treatments; no cows were under- or overconditioned. Regarding some IVGTT outcomes, such as maximal plasma glucose and baseline plasma insulin concentrations, results suggested that the biotin supplement combined with folic acid and vitamin $\mathrm{B}_{12}$ impaired glucose and insulin metabolism compared with the biotin supplement alone. One assumption that could be made to explain these results is that biotin supplementation probably impeded the use of vitamin $\mathrm{B}_{12}$ by cow cells. This is suggested by the fact that, for $\mathrm{B}_{9} \mathrm{~B}_{12}+$ cows, 
greater plasma vitamin $\mathrm{B}_{12}$ concentration was observed when cows were in the $\mathrm{B}_{8}+$ compared with the $\mathrm{B}_{8}-$ group. A similar observation was reported by Girard and Desrochers (2010), whereas Wang et al. (2018) did not find that biotin supplement had an effect on plasma vitamin $\mathrm{B}_{12}$ concentration. Insulin is known to suppress lipolysis (De Koster and Opsomer, 2013), hence decreasing plasma nonesterified FA concentration. For $\mathrm{B}_{8}+$ cows, even though no significant effect on nadir nonesterified FA was noted, it took more time to reach this nadir than $\mathrm{B}_{8}-$ cows. Hence, this result also suggested that $\mathrm{B}_{8}+$ cows had lower insulin sensitivity. The reason behind conflicting results regarding the effect of biotin supplementation on insulin sensitivity from the current study and experiments conducted in other species remains unknown, but could be related to the relative importance of gluconeogenesis for ruminants in opposition to nonruminants.

\section{CONCLUSIONS}

The week before conducting the IVGTT at 25 DIM, there were no differences in milk yield and components among treatments. Under the current conditions, even though a folic acid supplement, combined or not with vitamin $B_{12}$, has been shown to enhance insulin sensitivity in humans, a supplement of folic acid and vitamin $\mathrm{B}_{12}$ given to dairy cows from -27 to $28 \mathrm{~d}$ relative to the calving did not improve insulin sensitivity as suggested by IVGTT outcomes performed at about 25 DIM. However, for those cows, insulin response was faster as propounded by a shorter time to reach insulin peak compared with cows not receiving this supplement. Regarding the biotin supplement, results suggested that it modified the insulin response in early lactation as maximal plasma and AUC of insulin were greater. Further studies are necessary to understand the metabolic process behind this response.

\section{ACKNOWLEDGMENTS}

The authors are grateful to Valérie Beaudet, Véronique Roy, Liette Veilleux, Jasmin Brochu, Mario Léonard, Jocelyne Renaud (Agriculture et Agroalimentaire Canada, Sherbrooke, QC, Canada), William Poisson (Université Laval, Québec, QC, Canada), Lya Blais, and Myriam Beauregard (Université de Sherbrooke, Sherbrooke, QC, Canada) for technical support. We also acknowledge Marie-Ėve Bouchard, Étienne Viens, and the barn staff (Agriculture et Agroalimentaire Canada, Sherbrooke, QC, Canada) for animal care throughout the experiment. The present project was publicly supported research within Agriculture and Agri-Food
Canada (AAFC, Ottawa, ON, Canada; grant no. 1614). The authors have not stated any conflicts of interest.

\section{REFERENCES}

Aguilera-Mendez, A., M. G. Hernández-Equihua, A. C. Rueda-Rocha, C. Guajardo-López, R. Nieto-Aguilar, D. Serrato-Ochoa, L. F. Ruíz Herrera, and J. A. Guzmán-Nateras. 2018. Protective effect of supplementation with biotin against high-fructose-induced metabolic syndrome in rats. Nutr. Res. 57:86-96. https://doi.org/ 10.1016/j.nutres.2018.06.007.

Canadian Council on Animal Care. 2009. Guide to the care and use of experimental animals. Second ed. Vol. 1. E. D. Rolfert, B. M. Cross, and A. A. McWilliam, ed. Can. Counc. Anim. Care, Ottawa, Ontario, Canada.

Cardoso, F. C., W. Sears, S. J. LeBlanc, and J. K. Drackley. 2011. Technical note: Comparison of 3 methods for analyzing areas under the curve for glucose and nonesterified fatty acids concentrations following epinephrine challenge in dairy cows. J. Dairy Sci. 94:6111-6115. https://doi.org/10.3168/jds.2011-4627.

Cigerli, O., H. Parildar, A. Dogruk Unal, O. Tarcin, A. Kut, H. Eroglu, and N. Guvener. 2016. Vitamin deficiency and insulin resistance in nondiabetic obese patients. Acta Endocrinol. (Buchar) 12:319327. https://doi.org/10.4183/aeb.2016.319.

Combs, G. F. J., and J. P. McClung. 2017. The Vitamins. Fundamental aspects in nutrition and health. Fifth ed. Academic Press, Oxford, United Kingdom.

De Koster, J., M. Hostens, M. Van Eetvelde, K. Hermans, S. Moerman, H. Bogaert, E. Depreester, W. Van den Broeck, and G. Opsomer. 2015. Insulin response of the glucose and fatty acid metabolism in dry dairy cows across a range of body condition scores. J. Dairy Sci. 98:4580-4592. https://doi.org/10.3168/jds.2015-9341.

De Koster, J. D., and G. Opsomer. 2013. Insulin resistance in dairy cows. Vet. Clin. North Am. Food Anim. Pract. 29:299-322. https: //doi.org/10.1016/j.cvfa.2013.04.002.

Doepel, L., and H. Lapierre. 2010. Changes in production and mammary metabolism of dairy cows in response to essential and nonessential amino acid infusions. J. Dairy Sci. 93:3264-3274. https:// doi.org/10.3168/jds.2009-3033.

Duplessis, M., and C. L. Girard. 2019. Effect of maternal biotin, folic acid, and vitamin $\mathrm{B}_{12}$ supplementation before parturition on colostral and Holstein calf plasma concentrations in those vitamins. Anim. Feed Sci. Technol. 256:114241. https://doi.org/10.1016/j .anifeedsci.2019.114241.

Duplessis, M., H. Lapierre, and C. L. Girard. 2019. Supplements of biotin, folic acid and vitamin $\mathrm{B}_{12}$ : Their effects on cow metabolism during the transition period. J. Dairy Sci. 102(Suppl. 1):353.

Duplessis, M., H. Lapierre, D. Pellerin, J. P. Laforest, and C. L. Girard. 2017. Effects of intramuscular injections of folic acid, vitamin $\mathrm{B}_{12}$, or both, on lactational performance and energy status of multiparous dairy cows. J. Dairy Sci. 100:4051-4064. https://doi.org/ $10.3168 /$ jds.2016-12381.

Ferguson, J. D., D. T. Galligan, and N. Thomsen. 1994. Principal descriptors of body condition score in Holstein cows. J. Dairy Sci. 77:2695-2703. https://doi.org/10.3168/jds.S0022-0302(94)77212 $-\mathrm{X}$.

Gagnon, A., D. R. Khan, M. A. Sirard, C. L. Girard, J. P. Laforest, and F. J. Richard. 2015. Effects of intramuscular administration of folic acid and vitamin $B_{12}$ on granulosa cells gene expression in postpartum dairy cows. J. Dairy Sci. 98:7797-7809. https://doi .org/10.3168/jds.2015-9623.

Gärtner, T., E. Gernand, J. Gottschalk, and K. Donat. 2019. Relationships between body condition, body condition loss, and serum metabolites during the transition period in primiparous and multiparous cows. J. Dairy Sci. 102:9187-9199. https://doi.org/10 $.3168 /$ jds.2018-15762.

Girard, C. L., and A. Desrochers. 2010. Net flux of nutrients across splanchnic tissues of lactating dairy cows as influenced by dietary 
supplements of biotin and vitamin $B_{12}$. J. Dairy Sci. 93:1644-1654. https://doi.org/10.3168/jds.2009-2668.

Girard, C. L., J. J. Matte, and J. Lévesque. 1992. Responses of serum folates of preruminant and ruminant calves to a dietary supplement of folic acid. J. Anim. Sci. 70:2847-2851. https://doi.org/10 $.2527 / 1992.7092847 \mathrm{x}$

Girard, C. L., N. Vanacker, V. Beaudet, M. Duplessis, and P. Lacasse. 2019. Glucose and insulin responses to an intravenous glucose tolerance test administered to feed-restricted dairy cows receiving folic acid and vitamin $\mathrm{B}_{12}$ supplements. J. Dairy Sci. 102:6226-6234. https://doi.org/10.3168/jds.2019-16298.

Goff, J. P., and R. L. Horst. 1997. Physiological changes at parturition and their relationship to metabolic disorders. J. Dairy Sci. 80:1260-1268. https://doi.org/10.3168/jds.S0022-0302(97)76055 -7 .

Graulet, B., J. J. Matte, A. Desrochers, L. Doepel, M.-F. Palin, and C. L. Girard. 2007. Effects of dietary supplements of folic acid and vitamin $\mathrm{B}_{12}$ on metabolism of dairy cows in early lactation. J. Dairy Sci. 90:3442-3455. https://doi.org/10.3168/jds.2006-718.

Hayirli, A. 2006. The role of exogenous insulin in the complex of hepatic lipidosis and ketosis associated with insulin resistance phenomenon in postpartum dairy cattle. Vet. Res. Commun. 30:749774. https://doi.org/10.1007/s11259-006-3320-6.

Ho, M., J. H. Halim, M. L. Gow, N. El-Haddad, T. Marzulli, L. A. Baur, C. T. Cowell, and S. P. Garnett. 2014. Vitamin $B_{12}$ in obese adolescents with clinical features of insulin resistance. Nutrients 6:5611-5618. https://doi.org/10.3390/nu6125611.

Jaakson, H., P. Karis, K. Ling, A. Ilves-Luht, J. Samarütel, M. Henno, I. Jõudu, A. Waldmann, E. Reimann, P. Pärn, R. M. Bruckmaier, J. J. Gross, T. Kaart, M. Kass, and M. Ots. 2018. Adipose tissue insulin receptor and glucose transporter 4 expression, and blood glucose and insulin responses during glucose tolerance tests in transition Holstein cows with different body condition. J. Dairy Sci. 101:752-766. https://doi.org/10.3168/jds.2017-12877.

Jayashri, R., U. Venkatesan, M. Rohan, K. Gokulakrishnan, C. S. Shanthi Rani, M. Deepa, R. M. Anjana, V. Mohan, and R. Pradeepa. 2018. Prevalence of vitamin $B_{12}$ deficiency in South Indians with different grades of glucose tolerance. Acta Diabetol. 55:12831293. https://doi.org/10.1007/s00592-018-1240-x.

Karis, P., H. Jaakson, K. Ling, R. M. Bruckmaier, J. J. Gross, P. Pärn, T. Kaart, and M. Ots. 2020. Body condition and insulin resistance interactions with periparturient gene expression in adipose tissue and lipid metabolism in dairy cows. J. Dairy Sci. 103:3708-3718. https://doi.org/10.3168/jds.2019-17373.

Kerestes, M., V. Faigl, A. Kulcsar, O. Balogh, J. Foldi, H. Febel, Y. Chilliard, and G. Huszenicza. 2009. Periparturient insulin secretion and whole-body insulin responsiveness in dairy cows showing various forms of ketone pattern with or without puerperal metritis. Domest. Anim. Endocrinol. 37:250-261. https://doi.org/10.1016/j .domaniend.2009.07.003.

Lind, M. V., L. Lauritzen, M. Kristensen, A. B. Ross, and J. N. Eriksen. 2019. Effect of folate supplementation on insulin sensitivity and type 2 diabetes: A meta-analysis of randomized controlled trials. Am. J. Clin. Nutr. 109:29-42. https://doi.org/10.1093/ajcn/ nqy 234

Mann, S., F. A. L. Yepes, M. Duplessis, J. J. Wakshlag, T. R. Overton, B. P. Cummings, and D. V. Nydam. 2016. Dry period plane of energy: Effects on glucose tolerance in transition dairy cows. J. Dairy Sci. 99:701-717. https://doi.org/10.3168/jds.2015-9908.

McArt, J. A. A., D. V. Nydam, G. R. Oetzel, T. R. Overton, and P. A. Ospina. 2013. Elevated non-esterified fatty acids and $\beta$-hydroxybutyrate and their association with transition dairy cow performance. Vet. J. 198:560-570. https://doi.org/10.1016/j.tvjl .2013.08.011.

McFadden, J. W., C. L. Girard, S. Tao, Z. Zhou, J. K. Bernard, M. Duplessis, and H. M. White. 2020. Symposium review: One-carbon metabolism and methyl donor nutrition in the dairy cow. J. Dairy Sci. 103:5668-5683. https://doi.org/10.3168/jds.2019-17319.

National Farm Animal Care Council. 2009. Code of practice for the care and handling of dairy cattle. Dairy Farmers of Canada and National Farm Animals Care Council, Ottawa, ON, Canada.
National Research Council. 2001. Nutrient requirements of dairy cattle. Seventh revised ed. National Academy Press, Washington, DC, USA.

Orhan, C., O. Kucuk, M. Tuzcu, N. Sahin, J. R. Komorowski, and K. Sahin. 2018. Effect of supplementing chromium histidinate and picolinate complexes along with biotin on insulin sensitivity and related metabolic indices in rats fed a high-fat diet. Food Sci. Nutr. 7:183-194. https://doi.org/10.1002/fsn3.851.

Preynat, A., H. Lapierre, M. C. Thivierge, M. F. Palin, J. J. Matte, A Desrochers, and C. L. Girard. 2009. Influence of methionine supply on the response of lactational performance of dairy cows to supplementary folic acid and vitamin $\mathrm{B}_{12}$. J. Dairy Sci. 92:1685-1695. https://doi.org/10.3168/jds.2008-1572.

Radzicka, S., K. Ziolkowska, M. P. Zaborowski, J. Brazert, and M. Pietryga. 2019. Serum homocysteine and vitamin $B_{12}$ levels in women with gestational diabetes mellitus. Ginekol. Pol. 90:381-387. https://doi.org/10.5603/GP.2019.0066.

Reddi, A., B. DeAngelis, O. Frank, N. Lasker, and H. Baker. 1988. Biotin supplementation improves glucose and insulin tolerances in genetically diabetic KK mice. Life Sci. 42:1323-1330. https://doi .org/10.1016/0024-3205(88)90226-3.

Romero-Navarro, G., G. Cabrera-Valladares, M. S. German, F. M. Matschinsky, A. Velazquez, J. Wang, and C. Fernandez-Mejia. 1999. Biotin regulation of pancreatic glucokinase and insulin in primary cultured rat islets and in biotin-deficient rats. Endocrinology 140:4595-4600. https://doi.org/10.1210/endo.140.10.7084.

SAS Institute. 2012. User's Guide: Statistics. Version 9.4. SAS Institute, Cary, NC, USA.

Sasaki, Y., H. Sone, S. Kamiyama, M. Shimizu, H. Shirakawa, Y. Kagawa, M. Komai, and Y. Furukawa. 2012. Administration of biotin prevents the development of insulin resistance in the skeletal muscles of Otsuka Long-Evans Tokushima fatty rats. Food Funct. 3:414-419. https://doi.org/10.1039/c2fo10175k.

Schoenberg, K. M., R. M. Ehrhardt, and T. R. Overton. 2012. Effects of plane of nutrition and feed deprivation on insulin responses in dairy cattle during late gestation. J. Dairy Sci. 95:670-682. https: //doi.org/10.3168/jds.2011-4529

Wang, D. M., B. X. Zhang, J. K. Wang, H. Y. Liu, and J. X. Liu. 2018. Effect of dietary supplements of biotin, intramuscular injections of vitamin $\mathrm{B}_{12}$, or both on postpartum lactation performance in multiparous dairy cows. J. Dairy Sci. 101:7851-7856. https://doi .org/10.3168/jds.2018-14524.

Wei, X. S., C. J. Cai, J. J. He, C. Yu, F. Mitloehner, B. L. Liu, J. H. Yao, and Y. C. Cao. 2018. Effects of biotin and nicotinamide supplementation on glucose and lipid metabolism and milk production of transition dairy cows. Anim. Feed Sci. Technol. 237:106-117. https://doi.org/10.1016/j.anifeedsci.2018.01.012.

Zachut, M., H. Honig, S. Striem, Y. Zick, S. Boura-Halfon, and U. Moallem. 2013. Periparturient dairy cows do not exhibit hepatic insulin resistance, yet adipose-specific insulin resistance occurs in cows prone to high weight loss. J. Dairy Sci. 96:5656-5669. https: //doi.org/10.3168/jds.2012-6142.

Zimmerly, C. A., and W. P. Weiss. 2001. Effects of supplemental dietary biotin on performance of Holstein cows during early lactation. J. Dairy Sci. 84:498-506. https://doi.org/10.3168/jds.S0022 -0302(01)74500-6.

Zinicola, M., and R. C. Bicalho. 2019. Association of peripartum plasma insulin concentration with milk production, colostrum insulin levels, and plasma metabolites of Holstein cows. J. Dairy Sci. 102:1473-1482. https://doi.org/10.3168/jds.2017-14029.

\section{ORCIDS}

M. Duplessis (ำ https://orcid.org/0000-0003-3503-6612

C. L. Girard (ํ) https://orcid.org/0000-0002-5470-0841 